\title{
LEGAL IMPLEMENTATION AND EFFECTIVENESS OF FULFILLING POST DIVORCE CHILDREN
}

\author{
Musidah \\ Hakim Pengadilan Agama Tangerang \\ Email: musidah1@gmail.com
}

\begin{abstract}
In the study of Islamic law and positive law, children are the responsibility of parents until the child is an adult. But the most dominant in supporting the child is the male parent since the child came out of the mother's womb. In this study the focus is on the form of implementation and legal effectiveness of the decision on the livelihood of the child which imposes responsibilities to the father after the marriage break up due to divorce. This study aims to understand and analyze relating to the Implementation of Law and the Effectiveness of Post-Divorce Childhood Fulfillment. This study uses a qualitative approach, with the type of socio-legal studies or juridical-empirical research. The results showed that the implementation of the fulfillment of children's livelihoods after the breakup of marriage due to divorce can be said to not fully reach the target (not yet effective). So that judges are deemed necessary to take steps so that the fulfillment of children's living after divorce can be carried out, for the sake of legal certainty of children as victims of divorce from both parents.
\end{abstract}

Keywords: Childern, Post divorece, law, Indonesia,

\section{A. INTRODUCTION}

A marriage is broken because of divorce. As in article 38 of Law No. 1 of 1974 concerning Marriage 1 and Article 113 of the Compilation of Islamic Law that the termination of a marriage can occur due to death, divorce, and the court's decision. Whereas in Islamic law, divorce is due to the occurrence of khulu, zhihar, ila' and li'an (Ghozali, $2012: 220$ ). Then in the case of the Religious Court, the termination of the marriage can occur because of a request for divorce or divorce.

The problem of divorce in Indonesia does not go away and instead it increases every year, both among artists, officials and the people whose economy is middle-low and often with divorce cases. The phenomenon that affected the destruction of the household ark was not only evidenced by economic reasons, but lack of affection and emotional maturity.

However, divorce is not the last solution to resolve family conflicts, after divorce many things must also be accounted for in conjugal relations, especially those who have offspring, because the problems that often arise after divorce are problems of wife and child support, joint property and child care. 
Divorce brings legal consequences for both parties (husband and wife) and also for children born in marriage. The child must live in a family that is not harmonious as it should, for example, must live in a family with a single parent such as with a mother or with a father alone.

A divorce that occurs between a husband and a wife will have an impact on the 3 most important things, namely the breaking up of the relationship between husband and wife, the right to care for children which also includes the livelihood of the child, and the division of marital property must be divided into shared property. Children's rights are important to note because the child's presence in marriage raises the legal relationship between children and parents. This relationship raises the rights and obligations between parents and children, the relationship will continue until the child is an adult even though the marriage of both parents has broken.

Then in the case of post-divorce child living problems often become a problem because sometimes the rights of children are neglected and seriously neglected, especially those related to the basic rights of children, namely the cost of maintenance, education, shelter and visiting facilities the other. Even though parents are no longer united in one family, the problem of fulfilling the child's living remains the responsibility of parents and this should not be transferred to others, both parents, relatives, and others. In accordance with Law No. 1 of 1974 concerning Marriage article 41 paragraph 3 namely: The court may require the exhusband to provide living expenses and / or determine an obligation for the ex-wife. Then in the Compilation of Islamic Law, it is explained in article 56 point $d$, that all the costs of hadhanah and living for the child are the responsibility of the father according to his ability, at least until the adult child can take care of himself (21 years). In the case of fulfillment of a child's living after divorce, which is essentially the duty and duty of the father. Based on the word of Allah in verse al-Baqarah verse 233:

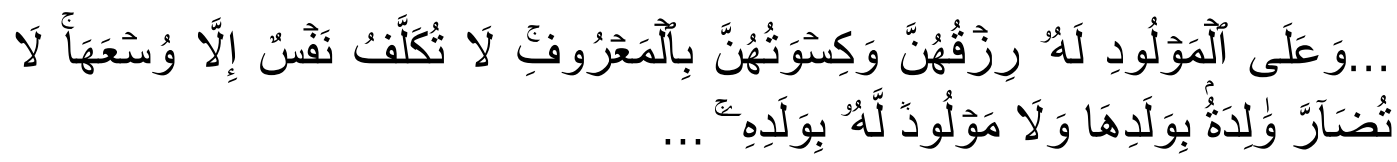
... And the father's obligation to feed and clothe the mothers in a sorry manner. Someone not burdened but according to ability levels. Let not a mother suffer misery because of her child and a father because of his child.

The phenomenon that occurs in the divorce process, the wife does not file a lawsuit again if the obligation of her ex-husband to fulfill the livelihood of the child is not carried out properly. Indeed, in essence in Marriage Law No. 1/1974 has been stated in article 41 paragraph 2 that if where the father is unable to fulfill his obligations in fulfilling the livelihood of the child here the court can determine that the mother also bears the cost. This decision will release the responsibility of the father, so that if the mother is unable to pay for the livelihood of the child, the child will be a victim and the child's future will not be directed properly and ultimately 
lead to juvenile delinquency due to the lack of attention and affection of his parents. Indeed, the purpose of bearing the burden of this child according to Yahya Harahap is to increase the sense of responsibility for the development and development of children's education (Harahap, $2009: 6$ ).

The majority of decisions about the livelihood of these children do not stand alone but are still included in divorce cases. Because the demand exists after divorce together with mut'ah and iddah. So to find out how many cases of child living, researchers look at divorce cases. So, from this aspect the role of the Religious Court which is an institution for settling civil cases such as divorce, childcare, fulfillment of living after divorce and so on is very much needed.

\section{B. METHOD}

The research method used in this research is descriptive method which aims to describe and describe the phenomena that exist in the field, namely scientific phenomena. Based on the description, the research seeks to examine the related implementation of the law and effectiveness of post-divorce child living.

\section{RESULTS AND DISCUSSIONS}

\section{Marriage Break}

Marriage termination is a legal term used in the marriage law to explain the end of a marriage relationship between a man and a woman who during her life as husband and wife. The most nertral term is divorce, but it is also difficult to use the term as a substitute for "termination of marriage" because divorce is one form of marriage breaking up (Syarifudin, 2006 : 189). As mentioned in Article 113 Compilation of Islamic Law (Intruksi Presiden R.I. Nomor 1 tahun 1991, 2001 : 56) and Article 38 of the Marriage Law that marriages can be terminated due to 3 (three) things, namely the cause of death, divorce and court decisions. Whereas in article 39 paragraph (1) the Marriage Law stipulates that divorce can only be conducted before a court hearing after the court concerned has tried and failed to reconcile.

Divorce is a divorce between a married couple as a result of their failure to carry out their respective role bonds. In this case divorce is seen as the end of a marriage instability

where a married couple then lives separately and is officially recognized by applicable law. Divorce is a family break up because one or both partners decide to leave each other so they stop doing their obligations as husband and wife.

Examination of divorce cases is explained in Law No. 7 of 1989 concerning the Religious Court, in terms of the divorce offender, then there are two kinds of divorce. There are two 
applications for divorce divorce, namely by husband to wife and divorce, namely by wife to husband.

\section{Making a Living in Islamic Law}

A living is taken from the word "الأنفاق" which means to issue (As'ad, n.d. : 197). A livelihood also means shopping, meaning something given by a husband to his wife, a father to a child, and relatives of his property as a basic necessity for them (Direktorat Jendral Pembinaan Kelembagaan Agama Islam, 2005 : 184).

The word maintenance means that all living expenses are the rights of his wife and children in terms of food, clothing and residence as well as several other basic necessities, even if the wife is a wealthy woman (Abdurrahman, $1992: 121)$.

From the above understanding it can be concluded, that a person's obligation to make a living to those who have the right to receive it, such as the husband has the right to provide for his wife, his children and even the main income given is intended to meet the basic needs of life, namely food, clothing and residence. The obligation to provide income is given according to ability, this can be adjusted to the needs and abilities to be in line with their circumstances and living standards. The same goes for poor relatives, and abandoned children.

A family up to a certain level or level must provide a living by those responsible for that family. This is consistent with the opinion expressed by Imam Hanafi that: "Every family to a certain degree or level has the right to be supported, if he is still a child and poor, weak or blind and destitute" (Abdurrahman, 1992 : 121).

Basic living law. Livelihood is the husband's obligation to his wife (even if the wife of a rich person), parents to their children, to their parents and to those who cannot afford it. Theorems that require a livelihood are as follows: Surat Ath-Thalaq verse (6), Surat AthThalaq verse (7) and Al-Baqarah veins verse: 233.

In article 45 of Law No. 1 of 1974:

Article (1): Both parents are required to maintain and educate their children to the best of their ability

Article (2): Parental obligations referred to in paragraph (1) of this article apply until the child marries or can stand alone. This obligation continues even though the marriage between the two parents breaks up.

Because if there is a divorce, the right to support the child is his father, if the father is unable, then the mother has the right to provide for his father. Between father and mother must 
deliberate in caring for and caring for the child, they must educate their children properly and properly.

If the child is breastfed at the time of the divorce, the mother is obliged to perfect her milk and the father is obliged to feed and clothe his child, and the wife's mother is entitled to a reward for milk.

In the case of Shafi'i and Hambali argued: "The woman who cared for was entitled to the caregiving wage she gave, whether she was her own mother or someone else's child" (Mughniyah, $2004:$ 137).

Thus it is clear that, in spite of the divorce between the parents, the maintenance of the child does not fail. The wife has the right to care for and feed the child, while the father has the right to provide food and clothing. This is in accordance with the Word of Allah SWT in Surah Al-Baqarah verse (233). Based on the argument above, it can be seen that the obligation of the father to provide for his children even though the father and mother have divorced. If there is something that causes the mother to not approve of her child, then in religion it is permissible for the child to be handed over to another woman to breastfeed, and the father is obliged to give rewards to the person who is breastfeeding his child ma'ruf.

Thus the obligation of parents to provide for their children who are in power. If the father is unable, then the mother is obliged to provide for his child, because God does not charge one of the parties but equally bear it according to their ability.

The existence of a living law does have a close correlation with the priority of men (rojulah) over women. As explained in the Qur'an in the verse an-Nisa verse 34 Allah confirms that the capacity of men is as Qawwam (leader) for women based on two factors, namely:

a. Tafdhil, the granting of privileges / more values by Allah swt through His prerogative paths in terms of physical, mentality, as well as the ability to control emotionality and stability of common sense.

b. Infaq Nafaqah, namely that men (ordered / charged) provide for their assets with women.

With regard to these two basic factors, while mufassir, including Al-Alusi and Haqqi, are rediscovered as illat from the provisions or capacity of men as qawwam for women. Both factors are stated illat, each in a different nature or characteristic. Tafdhil tends to be wahbi, that is, the absolute status of the male qawwam because it is a gift from Allah swt prerogatively without the intervention of human action. For the purpose of this Tafdhil, mufassir inventory anything that includes the privileges of men compared to women, namely nubuwwah (prophecy) and treatise (apostolate), al mulk al a'zham / walayah (caliphate I leadership), in matters of worship such as Friday prayers (prophecy) and treatises (apostolates), al mulk al a'zham / walayah (caliphate / leadership), in matters of worship such as Friday prayers (prophecy) and treatises (apostolate) and in congregation (imam of 
congregational prayer and congregation in the mosque), Shahadah (witnessing), Jihad (fighting kuffar and mushrikin), having more than one wife, divorce authority, dominance of inheritance, etc. While the livelihood factor or infaq, tends to be kasbi, that is, its relative existence, humans have a role (able to perform) to carry out the living which is ideally men who carry out the supporting role of women, so that the qawwam status of men automatically decreases / decreases levels wholeness, when the role of providing is not realized in his life. The livelihood factors referred to include giving dowry by the husband to his wife during marriage, earning during marriage, post-marital living namely iddah and mut'ah and subsistence of children.

Although these two factors have different characteristics, both are cumulative that must be understood in their entirety (both) in assessing the capacity and status of qawwam men for women. Thus it must be realized that the full fulfillment of the two factors requires different legal consequences. Men who do not meet the tafdhil factor in themselves (during his life), for example experiencing mental retardation, psychiatric disorders, permanent physical disabilities, the ghalib also will not meet the income factor, so this must be considered in assessing the legal implications. While men who only fulfill the tafdhil factor, while not carrying out the obligation to provide for example because he is lazy to try, not working / earning because of a minimum level of education and skills, as well as other reasons, then this too must be the basis of legal considerations in determining other rights and obligations that have a correlation with income in the context of family law.

\section{Overview of Children}

Based on Article 1 point (1) of Law no. 23 of 2002 concerning the Protection of Children a person can be said to be a child if "Someone who is not yet 18 years old including children who are still in the womb". Children have the right to protection, namely all activities to guarantee and protect children and their rights so that they can live, grow, develop, and participate optimally in accordance with human dignity and dignity, and are protected from violence and discrimination.

1) Provision of child support for husbands is obliged to pay for their children, namely spending to maintain and educational needs of their children. So it is clear that the livelihood is for his wife and children, while the liability is still valid, even though the wife has been divorced by her husband, even the ex-wife has the right to demand wages from her exhusband for breastfeeding her child (Article 41 of the Marriage Law).

2) Children's rights according to Law No. 23 of 2002 concerning Protection of Children Article 4: Every child has the right to be able to live, grow, develop and participate properly in accordance with human dignity and dignity, as well as get protection from violence and discrimination. Article 5: Every child has the right to a name as an identity and citizenship status. Article 6: Every child has the right to worship according to his religion, think and express according to his level of intelligence and age, in the guidance of parents. Article 9: 
Every child has the right to education and teaching in the context of personal development and intelligence according to their interests and talents.

3) Children's rights according to article 2 of Law no. 4 of 1979 concerning Child Welfare

a) The child has the right to welfare, care, care and guidance based on love both in his family and in special care to grow and develop properly.

b) Children have the right to service to develop their abilities and social life, in accordance with the culture and personality of the nation, to become good and useful citizens.

c) The child has the right to care and protection, both during the womb and after birth.

d) The child has the right to protection of the environment which can harm or hinder his growth and development properly.

4) Obligations and responsibilities of family and parents according to Law No.1 of 1974 concerning Marriage (Articles 45 and 46), that both parents are required to maintain and educate their children as well as possible, until the children marry or can stand alone, where obligations continue, even if the marriage between the two parents broke up. Children must respect their parents and obey their good will.

\section{Livelihood and Divorce (Breakup of Marriage Due to Divorce)}

The study of living, is considered to have a correlation with divorce institutions. The form of correlation is that because the livelihood is borne by the husband as a whole and authoritatively, starting from giving in the form of a dowry, as well as the livelihood during marriage and afterwards in the form of mut'ah, iddah and children, then it becomes (at least) one of the supporting reasons that divorce rights it is personally and authoritative also be with the husband. Thus, living has a central role in the existence of divorce in the hands of the husband. The central role, almost (too far) is understood as legal illat from divorce as the husband's authority. Even though the husband's inability to provide for a living can be the reason for the termination of marriage through the fasakh by the judge, this does not mean that the wife, because of her role as provider, is then entitled to the divorce from her husband. Anticipating this mistake, it must be understood that the right / authority of divorce is in the husband and not the wife, is a form of original law (ashl) explicitly outlined by the Qur'an and Al Sunnah as a source of law so that illat can not be sought with the assumption that if illat lost the law is gone. So even if for example something is forced to be declared as illathu kum in this case, then the concept of illat (or can be interpreted as qiyas) cannot be enforced in the original law, because the validity of the illat / qiyas instrument is only in the far'i law.

According to Imam al-Qurtubi talak as the husband's authority is final even though there are problems with the obligations of liability that they bear. While the wife who was apparently not supported by her husband, got the right to sue her husband's divorce by using the medium of sulthan in the case of a court institution (qadhi / judge), in the form of a marriage fasakh suit with his legal product in the form of divorce b'ain shughra (Al-Qurthuby, n.d. : 
169). This view is shared by the Shafi'iyyah and Malikiyah circles who assess the inability of the husband to pay for the wife's living, giving rise to the right for the wife to submit the marriage fasakh, assuming that the husband does not meet the capacity of qawwam, and the conditions for marriage which require cost / feasibility ability. livelihood (ba'ah), which is one of the functions of marriage. This is denied by Abu Hanifah with verse 280 of the Surah Al Baqarah.

The practice of religious justice, fasakh lawsuit in the form of bain shugra on the grounds of not being endowed, is generally carried out in the form of divorce suit by the wife. Shughra bain form. This is thus obtained from the khuluk path where the wife who took the initiative to ask for divorce because the fault is in her husband or her husband is the source of the reason for the lawsuit. The compilation of Islamic law accommodates this matter only implicitly, that is to put it in letter $\mathrm{g}$ Article 116 concerning the reasons for divorce, namely violation of divorce taklik, where one of them is not giving obligatory income for three months. The consequence is that the wife must pay iwadh Rp.10,000. In addition to that path, divorce bain shugra in the case of divorce on grounds not supported, can also be reached through fasakh, namely the termination of divorce by the judge. Through this route, the wife does not need to give iwadh. It's just that, specifically this is not mentioned in the Compilation of Islamic Law, but it will go into the provisions of the reason for divorce letter $f$, which is continuous disputes and quarrels and there is no hope of living in harmony again in the household. That is, not given a living if it is the cause of ongoing disputes between husband and wife, then in practice it will be terminated in the form of pure bain shugra..

\section{Obstacles in Realizing the Child's Living Rights After the Divorce}

Barriers that are often experienced during the implementation of providing child support after a divorce can be divided into 2 barriers, namely:

1) The Panel of Judges at the Religious Court has determined the amount of living the child must provide for his father each month. In practice, the income provided is less than specified and the gift is not routinely given every month. Such a situation goes on, because the party that nurtures and educates children, namely the mother, has never questioned or questioned the ex-husband (the child's father) or the mother could be resigned. The way to overcome this problem is that the mother who nurtures and educates children must have the courage to complain or sue the exhusband to fulfill the decision of the Religious Court.

2) In carrying out the execution of giving a living to children due to divorce the Religious Court has never supervised whether the decision was carried out in accordance with the decision of the Panel of Judges or not. The Religious Court only acts when the party that nurtures and educates the child (mother) reports to the Religious Court that the contents of the Religious Court Decree are not implemented properly or are not executed. In order to overcome this, the Religious Courts must be proactive in 
overseeing court decisions both with reports from aggrieved parties and with no reports, so that the decisions of the Religious Courts can be executed properly.

\section{CONCLUSSION}

Giving a child a living after a divorce is required by his parents, especially the father / father. However, if the father's condition is not possible to provide a living, then the mother is obliged to provide for the child. There is an obligation from the parents so that the child born from the marriage is not neglected due to the divorce of his parents.

Giving a child a living after a divorce is not carried out properly if those who care for and educate the child are not proactive to make full effort to implement a religious court ruling. in addition, the religious court must be proactive to oversee the execution of the decisions of the religious court.

In order for the child's living rights after a divorce to proceed smoothly, the Proactive Religious Court should supervise the implementation of executions relating to the provision of child support, those who care for and educate proactive children to implement the decisions of the religious court.

\section{Reference :}

Abdurrahman. (1992). Perkawinan dalam Syari'at Islam (1st ed.). Rineka Cipta.

Al-Qurthuby. (n.d.). Al Jami' li Ahkam Al Qura'n: Vol. V.

As'ad, A. (n.d.). Fathul Mu'in (Vol. 3). Menara Kudus.

Direktorat Jendral Pembinaan Kelembagaan Agama Islam. (2005). IImu Fiqih jilid II. Departemen Agama.

Ghozali, A. R. (2012). Fiqih Munakahat. Prenada Media Group.

Harahap, Y. (2009). Kedudukan Kewenangan Dan Acara Peradilan Agama UU No. 7 tahun 1989 (2nd ed.). Sinar Grafika.

Intruksi Presiden R.I. Nomor 1 tahun 1991. (2001). Kompilasi Hukum Islam di Indonesia.

Mughniyah, M. J. (2004). Figh Lima Madzhab. Lentera.

Syarifudin, A. (2006). Hukum Perkawinan Islam di Indonesia. Prenada Media Group. 